\title{
E-ISSN: 2580-5428 \\ PENGARUH CITRA MEREK DAN PERILAKU KONSUMEN TERHADAP KEPUTUSAN PEMBELIAN HANDPHONE BERBASIS ANDROID (STUDI KASUS MAHASISWA FAKULTAS EKONOMI DAN BISNIS UNSIKA)
}

\author{
Dini Yani, Puji Isyanto, Uus MD Fadli
}

\begin{abstract}
ABSTRAK
Tujuan Penelitian, untuk memperoleh bukti-bukti empirik dan menemukan kejelasan fenomena serta kesimpulan tentang Citra Merek dan Perilaku Konsumen Terhadap Keputusan Pembelian Handphone Berbasis Android pada Mahasiswa Fakultas Ekonomi dan Bisnis Universitas Singaperbangsa Karawang.

Penelitian dilakukan dengan menggunakan metode deskriptif kuantitatif dan verifikatif, yaitu : mengumpulkan, menyajikan, menganalisis, dan melakukan pengujian hipotesis serta membuat kesimpulan dan saran. Sampel dikumpulkan dengan menggunakan metode Stratified Random Sampling dengan jumlah sampel 182 responden dari populasi 380 orang. Teknik analisis data menggunakan teknik Analisis Rentang Skala dan Analisis Jalur dengan bantuan Methode Successive Interval (MSI), program computer Microsoft Excel 2010 dan SPSS versi 16. Dari hasil analisis data penelitian, diperoleh kesimpulan sebagai berikut:

Handphone berbasis android memiliki citra merek yang baik, Mahasiswa setuju berperilaku untuk membeli dan menggunakanya. Terdapat korelasi yang positif antara citra merek dan perilaku konsumen terhadap keputusan pembelian, serta terdapat pengaruh parsial dan simultan dari citra merek dan perilaku konsumen terhadap keputusan pembelian.
\end{abstract}

Kata Kunci : Citra Merek, perilaku konsumen, keputusan pembelian.

\section{A. PENDAHULUAN}

Perkembangan dunia modern dan globalisasi saat ini suatu kebutuhan akan komunikasi adalah hal yang sangat penting bagi setiap kalangan masyarakat. Kebutuhan tersebut berdampak pada meningkatnya permintaan akan berbagai jenis alat komunikasi yang mengakibatkan semakin banyaknya persaingan dalam dunia bisnis dibidang telekomunikasi. Hal tersebut dapat dilihat dari banyaknya produsen produk-produk alat komunikasi seperti handphone yang menawarkan berbagai jenis produk baru dengan inovasi yang berbeda dari pada produk-produk sebelumnya, yang dimana produk yang dihasilkan banyak memberikan kemudahan bagi para konsumen dalam melakukan komunikasi. Dari pada itu dunia bisnis produk komunikasi berlomba-lomba supaya dapat menarik minat para masyarakat dan memutuskan membeli serta menggunakan produknya. Hal ini juga merupakan langkah ataupun cara suatu perusahaan memberikan kepuasan terhadap konsumenkonsumen mereka yang sudah menggunakan produk-produk handphone jenis tertentu sebelumnya. 


\section{B. TINJAUAN PUSTAKA}

E-ISSN: 2580-5428

\section{Pengertian Citra Merek}

Suatu merek yang di lancarkan oleh produsen merupakan suatu janji produsen yang sifatnya spesifik, dan benefit yang ditawarkan kepada konsumen. Merek yang baik dan terkenal menjamin adanya tingkatan mutu atau kualitas. Menurut Kotler dalam buku Buchari Alma (2013:157) menyatakan ada 6 arti dari merek yaitu:

1. Attribute, (atribut) ada sesuatu atribut yang melekat pada suatu mereka misalnya barang mahal, mutu bagus, tahan lama, tidak luntur dsb.

2. Benefit, (manfaat) kata atribut diartikan sebagai functional dan emotional benefit. Istilah tahan lama bisa dikatakan functional benefit, sedangkan barang mahal ini, dapat diartikan emotional Obenefit, yang penting barang tersebut, biar mahal tapi sangat menguntungkan.

3. Value Barang, (nilai) mahal memiliki nilai tinggi bagi pengguna, karena dapat menaikkan gengsi/ prestige. Kenyamanan dan keselamatan.

4. Culture, (budaya) ini masalah budaya, yang terkesan, terkenal, efisien, selalu membeli barang berkualitas tinggi.

5. Personality, (kepribadian) memperlihatkan atau memberi kesan kepribadian tertentu, misalnya membeli mobil Mercedez, atau rolex menimbulkan kesan tersendiri bagi pemakai.

6. User, (pemakai) memberi kesan bahwa mayoritas pemakai produk tersebut adalah orang dari kelas sosial tertentu.

\section{Pengertian Perilaku Konsumen}

Dalam Buchari Alma (2013:101), dikatakan bahwa terdapat faktor-faktor yang mempengaruhi Perilaku Konsumen . Faktor-faktor tersebut adalah:

\section{Faktor sosial}

Berupa grup-grup yang turut mempengaruhi, dimana seseorang masuk sebagai anggota. Misalnya kelompok famili, teman, tetangga, teman sekerja, klub olahraga, klub seni, dsb.

2. Faktor budaya

Faktor budaya begitu banyak kelompoknya, mulai dari kelompok Negara, sampai kelompok etnis/ suku memiliki budaya dan kebiasaan dan alat sendiri. Di Negara kita ada budaya Sunda, Jawa, Minang, Batak, dsb, masing-masing, memiliki pola konsumsi dan barang kesenangan masing-masing.

3. Faktor pribadi

Yaitu yang menyangkut masalah usia, pekerjaan, jabatan, keadaan ekonomi pribadi, gaya hidup, kepribadian.

4. Faktor psikologis

Yaitu menyangkut motivasi seseorang untuk membeli apakah mengikuti teori motivasi Maslow atau karena dorongan sesuatu lainnya. Juga menyangkut masalah masalah persepsi seseorang terhadap sesuatu.

\section{Pengertian Keputusan Pembelian}

Proses psikologi dasar memainkan peranan penting dalam memahami bagaimana konsumen benar-benar membuat keputusan pembelian. Periset pemasaran telah mengembangkan "model tingkat" proses keputusan pembelian. Konsumen melalui lima 
tahap yaitu pengenalan masalah, pencarian informasi, evaluasi alternatif, keputusan pembelian dan perilaku pasca pembelian.

Konsumen tidak selalu melalui lima tahap pembelian produk itu seluruhnya. Mereka mungkin melewatkan atau membalik beberapa tahap. Meskipun demikian, model dalam gambar 2.2 memberikan kerangka referensi yang baik, karena model itu menagkap kiasan penuh pertimbangan yang muncul ketika konsumen menghadapi pembelian baru yang memerlukan keterlibatan tinggi. Berikut adalah gambar model lima tahap pembelian konsumen:

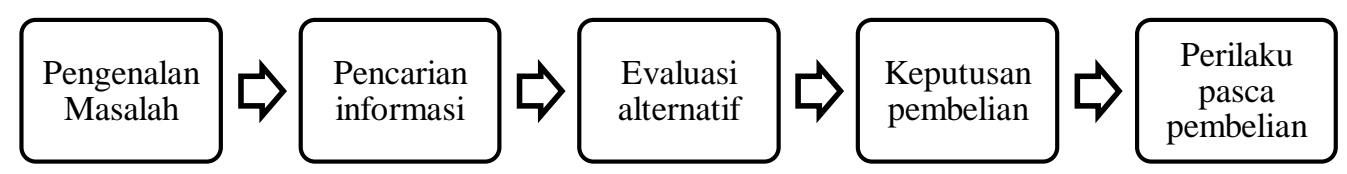

\section{Gambar 2.3 \\ Model Lima Tahap Pembelian Konsumen (Kotler dan Keller, 2009:184)}

Adapun proses pengambilan keputusan pembelian melalui tahapan-tahapan sebagai berikut:

1. Pengenalan Masalah

Proses pembelian dimulai ketika pembeli meyadari suatu masalah atau kebutuhan yang dipicu oleh rangsangan internal atau eksternal. Dengan rangsangan internal, salah satu dari kehidupan normal seseorang-rasa lapar, haus, seks-naik ke tingkat maksimum dan menjadi dorongan; atau kebutuhan bisa timbul akibat rangsangan eksternal.

2. Pencarian Informasi

Sumber informasi utama dimana konsumen dibagi menjadi empat kelompok:

a. Pribadi. Keluarga, teman, tetangga, rekan

b. Komersial. Iklan, situs beb, wiraniaga, penyalur, kemasan, tampilan.

c. Publik. Media masa, organisasi pemeringkat konsumen.

d. Eksperimental. Penanganan, pemerikasaan, penggunaan produk.

3. Evaluasi Alternatif

Setelah mendapatkan informasi dan merancang sejumlah pertimbangan dari produk alternative yang tersedia, konsumen siap untuk membuat suatu keputusan. Konsumen akan menggunakan informasi yang tersimpan di dalam ingatan, ditambah dengan informasi yang diperoleh dari luar untuk membangun suatu kriteria tertentu.

4. Keputusan Pembelian

Dalam tahap evaluasi, konsumen membentuk preferensi antarmerek dalam kumpulan pilihan. Dalam melaksanakan maksud pembelian, konsumen dapat membentuk lima subkeputusan: merek (merek A), penyalur (penyalur 2), kuantitas (satu computer), waktu (akhir minggu), dan metode pembayaran (kartu kredit).

5. Perilaku pascapembelian

Setelah pembelian, konsumen mungkin mengalami konflik dikarenakan melihat fitur mengkhawatirkan tertentu atau mendengar hal-hal menyenangkan tentang merek lain dan waspada terhadap informasi yang mendukung keputusannya. Kepuasan pascapembelian kepuasan merupakan fungsi kedekatan antara harapan dan kinerja anggapan produk. Jika kinerja tidak memenuhi harapan, konsumen kecewa; jika memenuhi harapan konsumen puas; jika melebihi harapan, konsumen sangat puas. Tindakan pascapembelian jika konsumen puas, mungkin ingin membeli produk itu kembali. Pelanggan yang puas juga cenderung mengatakan hal-hal baik tentang merek kepada orang lain. 
Dini Yani, Puji Isyanto, Uus MD Fadli

Vol 5 No 1

ISSN: $2528-0597$

E-ISSN: 2580-5428

\section{METODE PENELITIAN}

1. Desain Penelitian

Berdasarkan hasil penelitiannya desain penelitian ini merupakan penelitian survey dimana peneliti terjun langsung ke lapangan untuk memperoleh data dengan cara wawancara atau mengisi kuisioner.

2. Variabel Penelitian

Tabel 3.1

Data Variabel Penelitian

\begin{tabular}{|c|c|c|c|}
\hline Variabel & $\begin{array}{c}\text { Sub } \\
\text { Variabel }\end{array}$ & Indikator & $\begin{array}{c}\text { Nomor } \\
\text { Pernyataa } \\
\text { n }\end{array}$ \\
\hline \multirow{6}{*}{$\begin{array}{l}\text { Citra } \\
\text { Merek } \\
(\mathrm{X} 1)^{*}\end{array}$} & Atribut & $\begin{array}{ll}\text { 1. } & \text { Kemasan } \\
\text { 2. } & \text { Logo Merek } \\
\text { 3. } & \text { Warna } \\
\text { 4. } & \text { Nama Merek }\end{array}$ & $1,2,3,4$ \\
\hline & Manfaat & $\begin{array}{l}\text { 5. Manfaat Fungsional/keawetan } \\
\text { 6. Kemudahan Menggunakan } \\
\text { Produk } \\
\end{array}$ & 5,6 \\
\hline & Nilai & $\begin{array}{ll}\text { 7. } & \text { Harga } \\
\text { 8. } & \text { Kualitas Produk } \\
\text { 9. } & \text { Produk Terjamin } \\
\end{array}$ & $7,8,9$ \\
\hline & Budaya & $\begin{array}{l}\text { 10. Gaya Hidup } \\
\text { 11. Lingkungan }\end{array}$ & 10,11 \\
\hline & Kepribadian & $\begin{array}{l}\text { 12. Perasaan } \\
\text { 13. Penilaian Terhadap Produk }\end{array}$ & 12,13 \\
\hline & Pemakai & $\begin{array}{l}\text { 14. Status sosial seseorang } \\
\text { 15. Masyarakat Berbagai Umur }\end{array}$ & 14,15 \\
\hline \multirow[t]{4}{*}{$\begin{array}{l}\text { Perilaku } \\
\text { Konsumen } \\
(\mathrm{X} 2)^{* *}\end{array}$} & Sosial & $\begin{array}{ll}\text { 1. } & \text { Kelompok referensi } \\
\text { 2. } & \text { Keluarga } \\
\text { 3. } & \text { Peran dan Status sosial } \\
\text { 4. } & \text { Kepribadian dan Konsep diri }\end{array}$ & $1,2,3,4$ \\
\hline & Budaya & $\begin{array}{ll}5 . & \text { Budaya } \\
\text { 6. } & \text { Sub budaya } \\
\text { 7. } & \text { Kelas sosial }\end{array}$ & $5,6,7$ \\
\hline & Pribadi & $\begin{array}{ll}\text { 8. } & \text { Usia } \\
\text { 9. } & \text { Kondisi ekonomi } \\
\text { 10. } & \text { Kepribadian } \\
\text { 11. } & \text { Gaya hidup }\end{array}$ & $8,9,10,11$ \\
\hline & Psikologis & $\begin{array}{l}\text { 12. Motivasi } \\
\text { 13. Persepsi } \\
\text { 14. Pembelajaran } \\
\text { 15. Memori }\end{array}$ & $12,13,14,15$ \\
\hline
\end{tabular}


Tabel 3.1

Data Variabel Penelitian

(Lanjutan)

\begin{tabular}{|c|c|c|c|}
\hline Variabel & $\begin{array}{c}\text { Sub } \\
\text { Variabel }\end{array}$ & Indikator & $\begin{array}{c}\text { Nomor } \\
\text { Pernyataa } \\
\text { n }\end{array}$ \\
\hline \multirow{5}{*}{$\begin{array}{c}\text { Keputusan } \\
\text { Pembelian } \\
\text { (Y)*** }\end{array}$} & $\begin{array}{l}\text { Pengenalan } \\
\text { Masalah }\end{array}$ & $\begin{array}{l}\text { 1. Pengenalan Produk } \\
\text { 2. Kebutuhan }\end{array}$ & 1,2 \\
\hline & $\begin{array}{l}\text { Pencarian } \\
\text { Informasi }\end{array}$ & $\begin{array}{ll}\text { 3. } & \text { Sumber Komersial } \\
\text { 4. } & \text { Sumber Publik } \\
\text { 5. } & \text { Sumber Pengalaman }\end{array}$ & $3,4,5$ \\
\hline & $\begin{array}{l}\text { Evaluasi } \\
\text { Alternatif }\end{array}$ & $\begin{array}{ll}\text { 6. } & \text { Keyakinan } \\
\text { 7. } & \text { Sikap }\end{array}$ & 6,7 \\
\hline & $\begin{array}{l}\text { Keputusan } \\
\text { Pembelian }\end{array}$ & $\begin{array}{ll}\text { 8. } & \text { Pilihan Produk } \\
\text { 9. } & \text { Pilihan Merek } \\
\text { 10. } & \text { Pilihan Penyalur } \\
\text { 11. Jumlah Pembelian } \\
\text { 12. } & \text { Waktu Pembelian } \\
\end{array}$ & $\begin{array}{l}8,9,10,11, \\
12\end{array}$ \\
\hline & $\begin{array}{c}\text { Perilaku } \\
\text { Pasca } \\
\text { Pembelian }\end{array}$ & $\begin{array}{l}\text { 13. Metode Pembayaran } \\
\text { 14. Kepuasan Pasca Pembelian } \\
\text { 15. Tindakan Pasca Pembelian }\end{array}$ & $13,14,15$ \\
\hline
\end{tabular}

Sumber: Kotler dalam Buchari Alma (2013:157)*, Buchari Alma (2013:101)**, Phillip Kotler dan Kevin Lane Keller (2009:184)***.

\section{Metode Analisis Data}

\section{Analisis Jalur (Path Analysis)}

Untuk menganalisis hubungan antara variabel yang diteliti yaitu dengan menggunakan analisis jalur (path analysis). David Garson dari North Carolina State University, mendefinisikan bahwa analisis jalur sebagai " Model perluasan regresi yang digunakan untuk menguji keselarasan matriks korelasi dengan dua atau lebih model hubungan sebab akibat yang dibandingkan oleh peneliti”. Modelnya digambarkan dalam bentuk gambar lingkaran dan panah dimana anak panah tunggal menunjukan sebagai penyebab. Regresi dikenakan pada masingmasing variabel dalam suatu model sebagai variabel tergantung (pemberi respon) sedang yang lain sebagai penyebab. Pembobotan regresi diprediksikan dalam semua variabel dan dilakukan juga perhitungan uji keselarasan statistik. (David Gerson, 2003).

Analisis jalur digunakan untuk menguji pengaruh secara parsial (individual) dan silmutan (keseluruhan) dari variabel bebas (independent) atau disebut variabel eksogen terhadap variabel terikat (dependent) atau disebut variabel endogen. Melalui analisis jalur ini akan ditemukan jalur mana yang paling tepat dan singkat suatu variabel independent menuju variabel dependent yang terakhir dan juga menganalisis pola hubungan antar variabel dengan tujuan untuk mengetahui pengaruh langsung maupun tidak langsung seperangkat variabel bebas (eksogen) terhadap variabel terikat (endogan).

Dalam peneliatian ini terdiri atas 3 (tiga) variabel, yakni 1 (satu) variabel eksogen yaitu Citra Merek dan 2 (dua) variabel endogan yaituvariabel Perilaku Konsumen dan Keputusan Pembelian, maka hanya terdapat pengaruh langsung dan tidak langsung yaitu variabel eksogen yang mempengaruhi kedua variabel 
Dini Yani, Puji Isyanto, Uus MD Fadli

Vol 5 No 1

ISSN: 2528-0597

E-ISSN: 2580-5428

endogan. Untuk besarnya pengaruh langsung dinyatakan oleh koefisien jalur ( $p a t h$ coefficient) lambangnya " $\rho$ ".

Bedasarkan kajian teoritik dan uraian diatas yang melahirkan paradigm penelitian, maka untuk mempermudah pengujian statistika digambarkan diagram jalur (path analysis) pada Gambar 3.3 sebagai berikut:

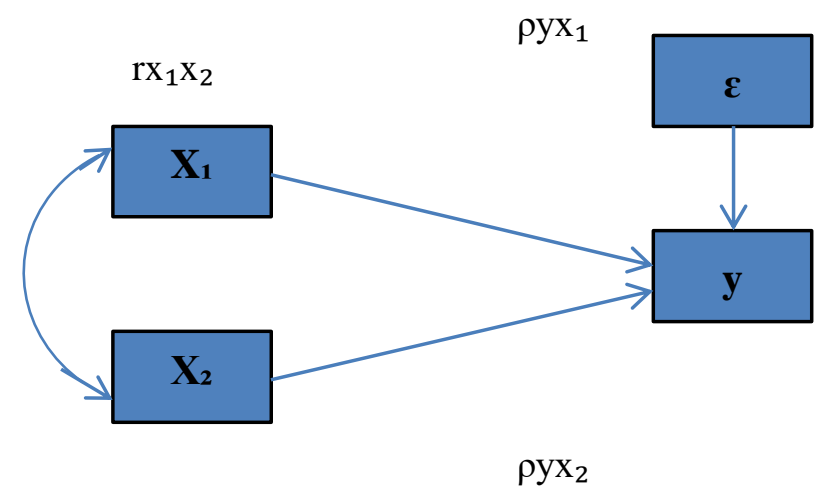

Gambar 3.3

Analisis Jalur

Sumber : Sugiyono (2014:156)

Persamaan analisis jalur, sebagai berikut:

$\mathrm{Y}=\mathrm{rx}_{1} \mathrm{x}_{2}+\rho \mathrm{yx}_{1}+\rho \mathrm{yx}_{2}+\varepsilon$

Dimana:

X1 : Citra Merek

X2 : Perilaku Konsumen

Y : Keputusan Pembelian

pyx : Koefisien jalur yang menggambarkan besarnya pengaruh langsung $\mathrm{X}$ terhadap $\mathrm{Y}$

$\varepsilon \quad$ : Variabel lain yang tidak diukur, tetapi mempengaruhi $\mathrm{Y}$

$\rho \mathrm{zx}_{1} \quad$ : Koefisien jalur yang menggambarkan besarnya pengaruh langsung $\mathrm{X}_{1}$ terhadap $\mathrm{Y}$

$\rho \mathrm{zx}_{2} \quad$ : Koefisien jalur yang menggambarkan besarnya pengaruh $\mathrm{X}_{2}$ terhadap $\mathrm{Y}$

$\mathrm{rx}_{1} \mathrm{rx}_{2}$ : Korelasi $\mathrm{X}_{1}$ dan $\mathrm{x}_{2}$

\section{Pengujian Hipotesis}

Uji hipotesis untuk mendeskripsikan ketiga variabel secara statistik, adalah sebagai berikut:

1. Pengujian korelasi antara citra merek dan perilaku konsumen (uji t).

Ho: $\rho \mathrm{x}_{1} \mathrm{x}_{2}=0$ : Tidak terdapat korelasi antara citra merek dan perilaku konsumen.

$\mathrm{H} 1: \rho \mathrm{x}_{1} \mathrm{x}_{2} \quad \neq 0 \quad$ : Terdapat korelasi antara citra merek dan perilaku konsumen.

Rumus:

$t=\frac{r \sqrt{n-2}}{\sqrt{1-r^{2}}} \quad$ dengan $\mathrm{dk}=\mathrm{n}-2$

Ho di tolak bila $\quad \mathrm{t}_{(\text {hitung) }} \leq-\mathrm{t}_{(1 / 2 \alpha)}$ atau $\mathrm{t}_{(\text {hitung) }} \geq \mathrm{t}_{(1 / 2 \alpha)}$

Ho diterima bila $\quad-\mathrm{t}_{(1 / 2 \alpha)} \leq \mathrm{t}_{\text {(hitung) }} \leq \mathrm{t}_{(1 / 2 \alpha)}$ 
2. Pengaruh parsial citra merek dan perilaku konsumen terhadap keputusan pembelian (uji t).

Ho : $\rho \mathrm{yx}_{1} ; \rho \mathrm{yx}_{2}=0$ : Tidak terdapat pengaruh parsial antara citra merek dan perilaku konsumen terhadap keputusan pembelian Handphone berbasis android.

$\mathrm{H} 1$ : $\rho \mathrm{yx}_{1} ; \rho \mathrm{yx}_{2} \neq 0$ : Terdapat pengaruh parsial antara citra merek dan perilaku konsumen terhadap keputusan pembelian Handphone berbasis android.

Rumus:

$$
t_{1}=\frac{P_{r x 1}}{\sqrt{\frac{\left(1-R^{2} r\left(x_{1} \ldots x_{2}\right) C R_{11}\right.}{n-k-1}}}
$$

3. Pengaruh simultan antara citra merek dan perilaku konsumen terhadap keputusan pembelian (uji F).

Ho: $\rho \mathrm{yx}_{1} ; \rho \mathrm{yx}_{2} ; \rho \mathrm{x}_{1} \mathrm{x}_{2}=0 \quad$ : Tidak terdapat pengaruh simultan antara citra merek dan perilaku konsumen terhadap keputusan pembelian Handphone berbasis android.

$\mathrm{H} 1: \rho \mathrm{yx}_{1} ; \rho \mathrm{yx}_{2} ; \rho \mathrm{x}_{1} \mathrm{x}_{2} \neq 0 \quad$ : Terdapat pengaruh simultan antara citra merek dan perialku konsumen terhadap keputusan pembelian Handphone berbasis android. Rumus:

$$
F=\frac{(n-k-1) R^{2} Y\left(X_{1} X_{2} \ldots X_{k}\right)}{k\left(1-R^{2} Y\left(X_{1} X_{2} \ldots X_{k}\right)\right)}
$$

\section{HASIL PENELITIAN DAN PEMBAHASAN 1. Rekapitulasi Variabel Citra Merek}

Tabel 4.28

\begin{tabular}{|c|c|c|c|}
\hline No & Indikator & Jml Skor & Keterangan \\
\hline 1 & Kemasan & 751 & Baik \\
\hline 2 & Logo Merek & 744 & Baik \\
\hline 3 & Warna & 797 & Sangat Baik \\
\hline 4 & Nama Merek & 758 & Baik \\
\hline 5 & Manfaat Fungsional/Keawetan & 786 & Sangat Bak \\
\hline 6 & Kemudahan Menggunakan Produk & 750 & Baik \\
\hline 7 & Harga & 711 & Baik \\
\hline 8 & Kualitas Produk & 716 & Baik \\
\hline 9 & Produk Terjamin & 716 & Baik \\
\hline 10 & Gaya Hidup & 734 & Baik \\
\hline 11 & Lingkungan & 746 & Baik \\
\hline 12 & Perasaan & 741 & Baik \\
\hline 13 & Penilaan Terhadap Produk & 777 & Sangat Baik \\
\hline 14 & Status Sosial Seseorang & 742 & Baik \\
\hline 15 & Masyarakat Berbagai Umur & 740 & Baik \\
\hline & Modus Jawaban Responden & 12.209 & Baik \\
\hline
\end{tabular}

Rekapitulasi Variabel Citra Merek $\left(\mathbf{X}_{1}\right)$

Sumber: Hasil Pengolahan Data, 2015. 
Dini Yani, Puji Isyanto, Uus MD Fadli

Vol 5 No 1

ISSN: $2528-0597$

E-ISSN: 2580-5428

\section{Rekapitulasi Variabel Perilaku Konsumen}

Tabel 4.46

Rekapitulasi Variabel Perilaku Konsumen $\left(\mathbf{X}_{2}\right)$

\begin{tabular}{|c|c|c|c|}
\hline No & Indikator & Jml Skor & Keterangan \\
\hline $\mathbf{1}$ & Kelompok Referensi & 744 & Setuju \\
\hline $\mathbf{2}$ & Keluarga & 741 & Setuju \\
\hline $\mathbf{3}$ & Peran dan Status Sosial & 768 & Sangat Setuju \\
\hline $\mathbf{4}$ & Kepribadian dan Konsep Diri & 732 & Setuju \\
\hline $\mathbf{5}$ & Budaya & 768 & Sangat Setuju \\
\hline $\mathbf{6}$ & Sub Budaya & 735 & Setuju \\
\hline $\mathbf{7}$ & Kelas Sosial & 765 & Sangat Setuju \\
\hline $\mathbf{8}$ & Usia & 729 & Setuju \\
\hline $\mathbf{9}$ & Kondisi Ekonomi & 777 & Sangat Setuju \\
\hline $\mathbf{1 0}$ & Kepribadian & 751 & Setuju \\
\hline $\mathbf{1 1}$ & Gaya Hidup & 796 & Sangat Setuju \\
\hline $\mathbf{1 2}$ & Motivasi & 749 & Setuju \\
\hline $\mathbf{1 3}$ & Persepsi & 794 & Sangat Setuju \\
\hline $\mathbf{1 4}$ & Pembelajaran & 736 & Setuju \\
\hline $\mathbf{1 5}$ & Memori & 737 & Setuju \\
\hline & Modus Jawaban Responden & $\mathbf{1 1 3 2 2}$ & Setuju \\
\hline
\end{tabular}

Sumber: Hasil pengolahan data, 2015.

\section{Rekapitulasi Variabel Keputusan Pembelian}

Tabel 4.64

Rekapitulasi Variabel Keputusan Pembelian (Y)

\begin{tabular}{|c|c|c|c|}
\hline No & Indikator & Jml Skor & Keterangan \\
\hline $\mathbf{1}$ & Pengenalan Produk & 731 & Setuju \\
\hline $\mathbf{2}$ & Kebutuhan & 691 & Setuju \\
\hline $\mathbf{3}$ & Sumber Komersial & 763 & Setuju \\
\hline $\mathbf{4}$ & Sumber Publik & 723 & Setuju \\
\hline $\mathbf{5}$ & Sumber Pengalaman & 764 & Setuju \\
\hline $\mathbf{6}$ & Keyakinan & 721 & Setuju \\
\hline $\mathbf{7}$ & Sikap & 731 & Setuju \\
\hline $\mathbf{8}$ & Pilihan Produk & 699 & Setuju \\
\hline $\mathbf{9}$ & Pilihan Merek & 762 & Setuju \\
\hline $\mathbf{1 0}$ & Pilihan Penyalur & 707 & Setuju \\
\hline $\mathbf{1 1}$ & Jumlah Pembelian & 731 & Setuju \\
\hline $\mathbf{1 2}$ & Waktu Pembelian & 731 & Setuju \\
\hline $\mathbf{1 3}$ & Metode Pembayaran & 759 & Setuju \\
\hline $\mathbf{1 4}$ & Kepuasan Pasca Pembelian & 738 & Setuju \\
\hline $\mathbf{1 5}$ & Tindakan Pasca Pembelian & 725 & Setuju \\
\hline & Modus Jawaban Responden & $\mathbf{1 0 9 7 6}$ & Setuju \\
\hline
\end{tabular}

Sumber: Hasil Pengolahan Data, 2015. 


\section{Analisis Korelasi Produk Moment}

E-ISSN: 2580-5428

Berikut ini akan dijelaskan analisis hasil korelasi antara citra merek dan perilaku konsumen Handphone berbasis android.

Tabel 4.66

Korelasi antara Citra Merek ( $\left.X_{1}\right)$ dan Perilaku Konsumen $\left(X_{2}\right)$ Correlations

\begin{tabular}{|rl|r|r|}
\hline & & $\mathbf{X}_{\mathbf{1}}$ & $\mathbf{X}_{\mathbf{2}}$ \\
\hline \multirow{3}{*}{$\mathbf{X}_{\mathbf{1}}$} & Pearson Correlation & 1 &, $836^{* *}$ \\
& Sig. (2-tailed) & &, 000 \\
& $\mathrm{~N}$ & 182 & 182 \\
$\mathbf{X}_{\mathbf{2}}$ & Pearson Correlation &, $836^{* *}$ & 1 \\
& Sig. (2-tailed) &, 000 & \\
$\mathrm{~N}$ & 182 & 182 \\
\hline
\end{tabular}

**. Correlation is significant at the 0.01 level (2-tailed).

Sumber : Hasil Pengolahan Data, 2015.

\section{Analisis Jalur (Path Analysis)}

Berikut ini akan dijelaskan analisis pengaruh parsial antara citra merek $\left(\mathrm{X}_{1}\right)$ dan perilaku konsumen $\left(\mathrm{X}_{2}\right)$ terhadap keputusan pembelian $(\mathrm{Y})$.

Tabel 4.67

Koefisien Jalur Untuk Setiap Variabel Citra Merek ( $X_{1}$ ) dan Perilaku Konsumen (X2) Terhadap Keputusan Pembelian (Y

Coefficients $^{\mathrm{a}}$

\begin{tabular}{|c|c|c|c|c|c|c|c|c|}
\hline \multirow[t]{2}{*}{ Model } & \multicolumn{2}{|c|}{$\begin{array}{l}\text { Unstandardized } \\
\text { Coefficients }\end{array}$} & \multirow{2}{*}{$\begin{array}{c}\begin{array}{c}\text { Standardized } \\
\text { Coefficients }\end{array} \\
\text { Beta }\end{array}$} & \multirow[t]{2}{*}{$\mathrm{T}$} & \multirow[t]{2}{*}{ Sig. } & \multicolumn{3}{|c|}{ Correlations } \\
\hline & B & $\begin{array}{l}\text { Std. } \\
\text { Error }\end{array}$ & & & & $\begin{array}{l}\text { Zero- } \\
\text { order }\end{array}$ & Partial & Part \\
\hline (Constant) & 7,949 & 2,015 & & 3,946 & ,000 & & & \\
\hline $1 \quad X_{1}$ & ,506 & ,078 &, 525 & 6,518 & ,000 & ,787 & ,438 & ,288 \\
\hline$X_{2}$ & 351 & 090, & ,314 & 3,905 & ,000 & ,753 & ,280 & 173 \\
\hline
\end{tabular}

a. Dependent Variable: $\mathrm{Y}$

Sumber : Hasil Pengolahan Data, 2015.

Berdasarkan dari tabel 4.67 di atas, menunjukan nilai Koefisien jalur untuk setiap variabel citra merek $\left(\mathrm{X}_{1}\right)$ dan perilaku konsumen $\left(\mathrm{X}_{2}\right)$ terhadap keputusan pembelian $(\mathrm{Y})$, nilai nilai koefisien jalur tersebut masing - masing dijelaskan sebagai berikut:

1. Pengaruh parsial citra merek $\left(\mathrm{X}_{1}\right)$ terhadap keputusan pembelian (Y). Berdasarkan tabel koefisien jalur untuk variabel citra merek $\left(\mathrm{X}_{1}\right)$ terhadap keputusan pembelian (Y) adalah sebesar 0,525. Hal ini menunjukan bahwa pengaruh langsung variabel citra merek $\left(\mathrm{X}_{1}\right)$ terhadap keputusan pembelian $(\mathrm{Y})$ adalah sebesar 0,525 sehingga diperoleh persamaan $\mathrm{Y}=0,525 \mathrm{X}_{1}$. 


\section{Analisis Koefisien Determinasi}

Total pengaruh variabel citra merek $\left(\mathrm{X}_{1}\right)$ dan perilaku konsumen $\left(\mathrm{X}_{2}\right)$ terhadap keputusan pembelian $(\mathrm{Y})$ adalah besaran koefisien determinasi $\left(\mathrm{R}^{2}\right)$ terlihat pada tabel dibawah ini:

Table 4.71

pengaruh variabel citra merek $\left(X_{1}\right)$ dan perilaku konsumen $\left(X_{2}\right)$ terhadap keputusan pembelian (Y).

\section{Model Summary}

\begin{tabular}{|l|c|r|r|c|}
\hline Model & $\mathrm{R}$ & $\begin{array}{c}\mathrm{R} \\
\text { Square }\end{array}$ & $\begin{array}{c}\text { Adjusted } \\
\mathrm{R} \\
\text { Square }\end{array}$ & $\begin{array}{c}\text { Std. } \\
\text { Error of } \\
\text { the } \\
\text { Estimate }\end{array}$ \\
\hline 1 &, $806^{\mathrm{a}}$ &, 650 &, 646 & 5,35322 \\
\hline
\end{tabular}

a. Predictors: (Constant), $\mathrm{X}_{2}, \mathrm{X}_{1}$

Sumber : Hasil Pengolahan Data, 2015.

koefisien determinasi adalah $\mathrm{R}$ Square $=0,650$ berarti variabel keputusan pembelian $(\mathrm{Y})$ dapat dijelaskan oleh variabel citra merek $\left(\mathrm{X}_{1}\right)$ dan perilaku konsumen $\left(\mathrm{X}_{2}\right)$ sebesar $65 \%$ sedangkan sisanya $35 \%$ dijelaskan oleh faktor-faktor lain yang tidak diteliti $(\varepsilon)$.

\section{E. KESIMPULAN DAN SARAN}

Kesimpulan dari hasil penelitian mengenai Pengaruh Citra Merek dan Perilaku Konsumen terhadap Keputusan Pembelian Handphone berbasis android (Studi Kasus Mahasiswa Fakultas Ekonomi dan Bisnis UNSIKA.

1. Hasil penelitian tentang Citra Merek Handphone berbasis android (Studi Kasus Mahasiswa Fakultas Ekonomi dan Bisnis UNSIKA) adalah memiliki citra merek yang baik pada Mahasiswa.

2. Hasil penelitian tentang Perilaku Konsumen Handphone berbasis android (Studi Kasus Mahasiswa Fakultas Ekonomi dan Bisnis UNSIKA) adalah Mahasiswa setuju untuk memutuskan membeli dan menggunakan Handphone berbasis android.

3. Hasil penelitian tentang Keputusan Pembelian Handphone berbasis android (Studi Kasus Mahasiswa Fakultas Ekonomi dan Bisnis UNSIKA) adalah Mahasiswa setuju untuk melakukan pembelian Handphone berbasis android.

4. Hubungan antara citra merek dan perilaku konsumen dilihat dari besarnya korelasi dari kedua variabel tersebut adalah sebesar 0,836, artinya terdapat korelasi yang sangat kuat antara citra merek dan perilaku konsumen pada Mahasiswa Fakultas Ekonomi dan Bisnis UNSIKA sebagai pengguna Handphone berbasis android. 
5. Terdapat Pengaruh parsial antara citra merek terhadap keputusan pembelian adalah sebesar 0,525 sedangkan pengaruh parsial antara perilaku konsumen terhadap keputusan pembelian adalah sebesar 0,314. Citra merek $(0,525)$ lebih tinggi dibandingkan perilaku konsumen $(0,314)$, artinya citra merek lebih berpengaruh terhadap keputusan pembelian dibandingkan dengan perilaku konsumen.

6. Terdapat Pengaruh simultan antara citra merek dan perilaku konsumen terhadap keputusan pembelian adalah besaran koefisien determinasi $\left(\mathrm{R}^{2}\right)$ yaitu 0,650 atau sebesar $65 \%$. Adapun pengaruh lain diluar model yang tidak diteliti adalah 0,35 atau sebesar $35 \%$.

\section{F. SARAN}

\section{Saran pada Handphone Berbasis Android}

Sehubungan dengan penelitian yang telah penulis lakukan, ada beberapa hal yang perlu di perhatikan oleh Handphone berbasis android.

1. Saran citra merek

Berdasarkan hasil penelitian tentang citra merek handphone berbasis android adalah termasuk dalam skala baik, maka dari itu citra merek ini perlu dipertahankan atau mungkin ditingkatkan demi terciptanya keputusan pembelian yang lebih pada Handphone berbasis android oleh Perusahaan.

2. Saran perilaku konsumen

Berdasarkan hasil penelitian tentang perilaku konsumen pengguna Handphone berbasis android adalah termasuk dalam skala setuju, maka dari itu Perusahaan harus dipertahankan atau mungkin ditingkatkan perilaku konsumen pengguna Handphone berbasis android demi terciptanya keputusan pembelian yang lebih pada Handphone berbasis android.

3. Saran keputusan pembelian

Berdasarkan hasil penelitian tentang keputusan pembelian Handphone berbasis android adalah termasuk dalam skala setuju, maka dari itu keputusan pembelian ini perlu dipertahankan atau mungkin ditingkatkan oleh Perusahaan.

4. Saran hubungan antara citra merek dan perilaku konsumen

Hubungan antara citra merek dan perilaku konsumen sangat berkaitan, karena dengan memiliki citra merek dengan baik maka akan meningkatkan perilaku konsumen yang baik juga pada Handphone berbasis android.

5. Saran pengaruh parsial dari citra merek dan perilaku konsumen terhadap keputusan pembelian pada Handphone berbasis android. Pengaruh secara parsial variabel perilaku konsumen terhadap keputusan pembelian lebih besar dibandingkan variabel citra merek terhadap keputusan pembelian . Maka dari itu harus lebih memperhatikan citra merek agar keputusan pembelian Handphone berbasis android tidak semakin menurun.

6. Saran pengaruh simultan dari citra merek dan perilaku konsumen terhadap keputusan pembelian pada Handphone berbasis android. Pengaruh simultan dari citra merek dan perilaku konsumen terhadap keputusan pembelian lebih besar dibandingkan dengan variabel lain yang tidak diteliti oleh penulis. Maka dari itu harus lebih memperhatikan citra merek dan perilaku konsumen agar keputusan pembelian Handphone berbasis android tidak semakin menurun.

\section{G. DAFTAR PUSTAKA}


Dini Yani, Puji Isyanto, Uus MD Fadli

Vol 5 No 1

ISSN: $2528-0597$

E-ISSN: 2580-5428

Alma, Buchari. 2013. Manajemen Pemasaran dan Pemasaran Jasa. Bandung, ALFABETA

Fadli, Uus MD. 2014. Metodelogi Penelitian. Karawang, Fakultas Ekonomi. UNSIKA

Hasibuan, Malayu S.P.2011.Manajemen Dasar, Pengertian, dan Masalah. Edisi Revisi. Jakarta, Bumi Aksara

Huda, Arif Akbarul. 2012. Pemograman Android 24 Jam. Yogyakarta, ANDI.

Kotler, Philip dan Kevin Keller. 2009. Manajemen Pemasaran. Jakarta, Erlangga

Paramitha, Sekar. 2014. Buku Sakti Menulis Skripsi, Tesis \& Disertasi (kurang dari 30 hari). Yogyakarta, Araska

Santoso, Singgih. 2014. Statistik Multivariat. Konsep dan Aplikasi dengan SPSS. Edisi Revisi. Jakarta,Kompas Gramedia

Sugiyono. 2013. Cara Mudah Menyusun Skripsi, Tesis, dan Disertasi. Bandung, ALFABETA. Bandung

2014. Metode Penelitian Kuantitatif Kualitatif dan $R \& D$. Bandung. ALFABETA

Sunyoto, Danang. 2013. Perilaku Konsumen. Panduan Riset Sederhana Untuk Mengenali Konsumen. Yogyakarta. CAPS (Center of Academic Publishing Service)

Supranto, J. 2011. Perilaku Konsumen Untuk Memenangkan Persaingan Bisnis. Edisi 2. Jakarta, Mitra Wacana Media

Sumarwan, Ujang. 2011. Perilaku Konsumen Teori dan Penerapannya Cetakan 1 Edisi Ke 2. Bogor, Ghalia Indonesia

Swastha, Bayu dan Irawan. 2008. Menejemen Pemasaran Modern. Yogyakarta. Liberty Yogyakarta

Tjiptono, Fandy. 2014. Pemasaran Jasa. Yogyakarta,Andi Yogyakarta

JURNAL

Marlina, Gita. 2013. Pengaruh Kualitas Produk dan Citra Merek Terhadap Keputusan Pembelian Handphone Blackberry. Fakultas Ekonomi Univeritas Singaperbangsa Karawang

Wandani, 2013. Analisis Persepsi Konsumen dalam Memilih Merek Mobil Studi Kasus Toyota Avanza dan Daihatsu Xenia di Wilayah Kabupaten Karawang. Fakultas Ekonomi Universitas Singaperbangsa Karawang

Hamidah, Siti. 2013. Analisis Presepsi Citra Merek, Desain, Fitur dan Pengaruhnya Terhadap Keputusan Pembelian Produk Handphone Samsung Berbasis Android (Studi Kasus STIE Pelita Indonesia). STIE Pelita Indonesia

Malviya, Surendra. 2013. A Study on the Factors Influencing Consumer's Purchase Decision towards Smartphones in Indore. International Institute of Professional Studies, DAVV, Indore - India

\section{INTERNET}

Stat Counter Global Stat. Maret 2015. (http://gs.statcounter.com/\#mobile_os-wwmonthly-201403-201503-bar). Sabtu, pkl. 14.05 WIB.

IDC Worldwide Quarterly mobile phone tracker, Jumat, 9 Januari 2015, pkl. 09:32 am. http://www.idc.com/getdoc.jsp?containerId=prUS25037214

http://www.gartner.com/technology/analysts.jsp

Referensi:http://id.wikipedia.org/wiki/Android(sistem operasi)\#Sejarah. 18 Nov 2014. $\underline{11.24 \mathrm{WIB}}$ 